\title{
The Dark Blue Exile of Jaroslav Ježek
}

\section{MICHAEL BECKERMAN}

It is tempting to regard any dramatic situation of exile as symbolic of exile in a broader sense. At first glance this might be true of Jaroslav Ježek's exile, as he arrived in New York in 1939 mostly blind and with few prospects. A superstar in Czechoslovakia, he was very much a forgotten man for most of his time in the United States. But like all such historical dramas, there are many sides, nuances and versions of the same story. While as I hope to show, Ježek's exile was in several senses, "Dark Blue," the effect of the coloration depends on how you look at it.

\section{The Gleaming Speed of Home: Ježek in Prague}

In 1926 the Czech racing car driver Eliška Junková took second place at the Klausenpass in Switzerland and within a year or so her compatriot Jaroslav Ježek had commemorated her vehicle of choice in a sleek raglike piece called "Bugatti Step." It quickly became a big hit. With an introduction melding the speed of the Bugatti with the honk of a car horn, the composition captures the edgy lightness of what was something like a Czech Jazz Age:

\section{Audio Example 1: Bugatti Step}

Accessible at: http://dx.doi.org/10.3998/mp.9460447.0002.201

Artist: Ježek Band

For the next ten years Ježek was the toast of Prague, spinning out hit after hit and making a reputation for himself as "the Czech Gershwin" while continuing to compose "serious" art music (he had studied with Josef Suk).

\section{Audio Example 2: Etude}

Accessible at: http://dx.doi.org/10.3998/mp.9460447.0002.201

Born with poor eyesight, on exactly the same day as Dmitri Shostakovich, a series of operations had left Ježek nearly blind, but he was able to excel both as a pianist and as a composer. In the late 1920's he teamed up with the "clown intellectuals" Jiří Voskovec and Jan Werich to create a new kind of edgy cabaret called the "Osvobozené Divadlo" or the "Liberated Theater." The Ježek big band put together for these spectacles, was one of the best in Europe, either playing the composer's compositions, or international ones:

The author would like to thank the following people for their help in putting this article together: Aleš Březina, Jan Svěrák, Zuzana Vanišová, Miloš Krajný, Radek Boschetty, Erik Entwistle, Zoja Seyčková, Brian Locke, and Joseph Straus. The author would like to offer special thanks to Bruno Nettl for his contributions to this article. 


\section{Audio Example 3: Já zpívám tobě jen}

Accessible at: http://dx.doi.org/10.3998/mp.9460447.0002.201

Artist: Ježek Band

Many of their songs from that time became Czech classics, and it is noteworthy that despite enormous differences in tone and effect, his jazz-influenced songs use dissonance in very much the same way as his more academic compositions, and in some cases eerily foreshadow some of the technical tics of hard bop such as this example from the opening of "Život je jen nahoda" (Life is just coincidence), one of his biggest hits:

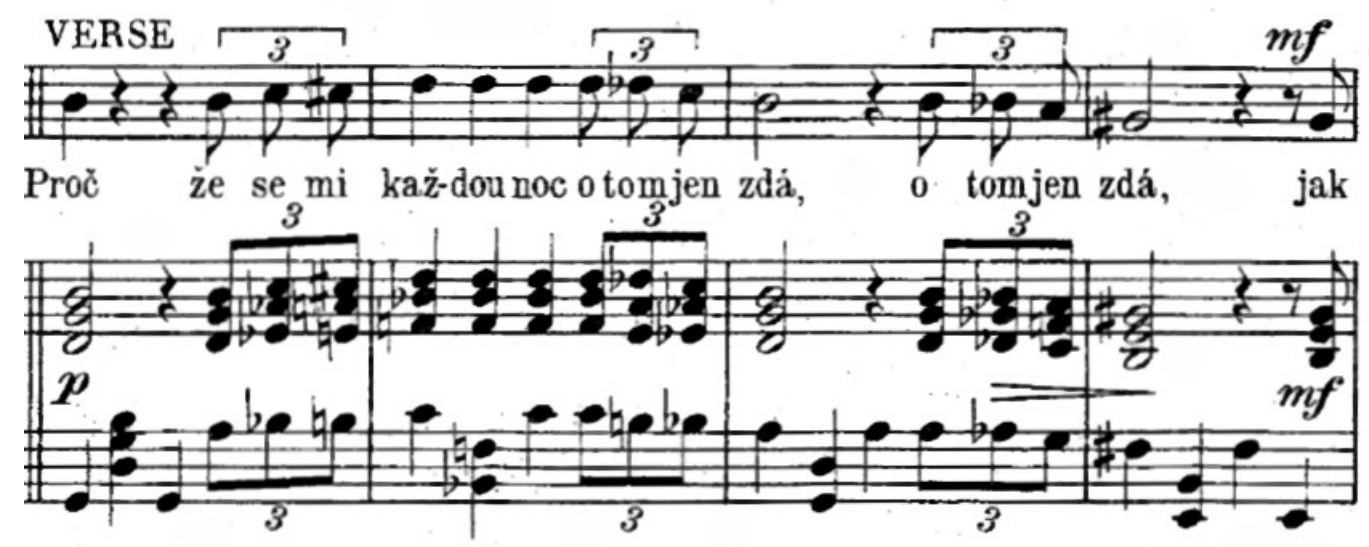

Figure 1. "Život je jen nahoda."

By the late 1930's the situation for the theater troupe had become precarious and the political satire that animated the Liberated Theater was to end summarily with the Munich Agreement. Seeing the handwriting on the wall Ježek got out of Prague several months before the Nazi invasion in March of 1939.

Some of the energy of the time is captured in two brief clips. The first shows Ježek dancing dreamily to the strains of unheard music:

\section{Video Example 1}

Accessible at: http://dx.doi.org/10.3998/mp.9460447.0002.201

The second shows the kind of excitement generated by the Liberated Theater (note the audience response) and also reveals a couple of other touches, including the surrealistic map of Europe you will see at the beginning as a political statement, and a jazzy patter song that deals with David and Goliath. A free translation is offered below: 


\section{Video Example 2}

Accessible at: http://dx.doi.org/10.3998/mp.9460447.0002.201

People beating each other bloody, man against man like executioners

Take a look at this, I have to tell you about it:

The giant is beating up the midget, he's sure that he'll win.

Let's relax in a nice chair and read the bible, the whole story is in there:

The book of Samuel tells us how a great misfortune befell the Jews:

How the nasty Philistines were anything but lazy when it came to waruntil they met David, that is.

David went off to war nonchalantly. He carried little sugar cakes with him for his brethren.

As they marched he practiced his tosses just in case.

"Hey there, where are you going? Boy are you tiny!"

In this way Golitah tried to provoke David. But David just politely saluted.

But when the giant spit in his eye, David swung his slingshot around. "You're tough before the fighting starts, but I'll show you. You're big, but I've got courage!” And that was the end of Goliath.

While hindsight makes the idea of a little Jewish David humorously triumphing over a "calamitous enemy" in 1938 somewhat difficult to digest today, it is a song of enormous charm and ingenuity.

\section{How Much Home Does a Person Need? Or Pears Don't Ripen in Kamchatka}

In his philosophical meditation At the Mind's Limits, Jean Amery asks: "How much home does a person need?” and describes his own experience of exile:

There was no order in this world. Was the smile of the police official who checked out our papers good-natured, indifferent, or mocking? Was his deep voice resentful or full of goodwill? I didn't know. Did the old bearded Jew, whose gurgling sounds I nevertheless grasped as sentences, mean it well with us or did he hate us, because by our mere presence on the streets of the city we incited against him the native population which was already tending towards antiSemitism. ${ }^{1}$

We may compare this with remarks that Ježek made in an interview with radio station WOR in 1941: "Americans are tired of emigrants because they worry too much and talk about the war all the time."

Two years earlier, in January of 1939 Ježek had left Czechoslovakia never to return. His friend Gustav Janouch, seeking to put a good spin on things said, "Ah, you're going to America, the home of jazz. Maybe it will be a good thing for your music.” Ježek responded harshly:

\footnotetext{
${ }^{1}$ Jean Amery, At the Mind’s Limits (Indiana University, 1980), 47.
} 
Don't give me that nonsense. Don't speak so stupidly and thoughtlessly. Pears don't ripen in Kamchatka. My music was planted here, in this land, in this soil. It's something you can't take with you. We can't just pop our homeland in a suitcase. A homeland-that is air, pavement, language people-that is what you must leave behind. So what's going to be good for me there? Nothing. Nothing at all. Maybe I'm fleeing from one death to another. ${ }^{2}$

By the Spring of 1939, Ježek had arrived and taken up residency in New York, mostly on Riverside Drive. Certainly, despite his worries, he was better off than many; he had friends, he was well known back home and something of celebrity in local circles. But he had immense difficulties getting acclimated. Put simply: he was blind, had no real source of income and cound not really speak English. As his radio interviewer remarked: "When he masters the language a bit better he hopes that he will write popular music and songs." Until proven otherwise, Ježek was considered an alien by the government, and was not able to get any official working permit. In the same interview he says:

I can't write musical comedies because I'm only on a visitor's visa. I'm waiting to be worked into the quota. In the meantime I'm not allowed to work as a composer because the Union has not given me permission.

Unable to work in musical theater, in May 1940, he got a job conducting a worker's choir, and threw himself into this work. He saw the success of colleagues such as Bohuslav Martinů and Rudolf Firkušný, but had trouble adjusting and getting to work on larger projects. (I interviewed Firkušný shortly before his death, and he made a point of telling me that Ježek expected to be a big success in the United States and never really got over the fact that he was having such difficulties.) Meanwhile, his pals Voskovec and Werich were having an easier time of it, with successes in Cleveland with "Heavy Barbara" the revue featuring "David and Goliath," and a move to Hollywood (where Voskovec would become famous as "Juror \#11" in Sidney Lumet's Twelve Angry Men.) Despite some setbacks however, Ježek, did have a plan to put himself on the musical map.

\section{How and Why Ježek's Sonata Was Lost and Found}

By the beginning of 1941 Ježek was finally able to focus on and complete some large scale pieces, and by the beginning of March, 1941 he had completed a four movement piano sonata. He described his feelings in a letter to Werich's wife Zdena:

I finished one of my works and have already played it for Rudolf Firkušný who, it seemed to me, liked it very much. It's a piano sonata. I worked on it rather slowly while in the past I would have done it much faster. But it seems to me that all in all it's a pretty respectable work which could represent me well. After finishing this sonata I now have a much greater appetite for further work since I'm beginning to understand a few things here and there and think that maybe I'm not such a bad composer after all, as I had begun to think. ${ }^{3}$

Perhaps on the basis of Firkušnýs approval and with obvious renewed confidence, Ježek submitted the work it to the International Society for Contemporary Music for consideration in an

\footnotetext{
${ }^{2}$ František Cinger, Happy Blues or From the Diary of Jaroslav Ježek [Štast’né Blues aneb z deníku Jaroslava Ježka] (Prague, 2006), 147.

${ }^{3}$ Letter to Zdena Werich, March 5, 1941.
} 
upcoming concert series. About two weeks after Ježek wrote the letter to Zdena Werich, the following appeared in the New York Times:

\begin{abstract}
The jury of the International Society for Contemporary Music has selected chamber works by nineteen composers for performance here at its festival, which will be held for the first time in the United States next May. Five of the composers-Edward Cone, Aaron Copland, Russell G. Harris, Emil Koehler and Paul Nordoff-are Americans, this country will have the largest representation in the chamber music division. Other composers and their countries are Paul $\mathrm{Ka}$ dosa and Matyas Seiber (Hungary), Salvador Contreras and the late Silvestre Revueltas (Mexico), Jerzy Fitelberg and Antoni Szalowski (Poland), Juan Carlos Paz (Argentina), Alejandro Garcia Caturla (Cuba), Jaroslav Jerek (Czecho-Slovakia), René Leibowitz (France), William Alwyn (Great Britain), Piet Ketting (Netherlands) and Edmond Partos (Palestine). Paul Dessau, Artur Schnabel, Anton Webern and Stefan Wolpe, being men without countries, are listed as "Independent."
\end{abstract}

Figure 2. New York Times, March 16, 1941. (pg. X7)

Among the composers named we find "Jaroslav Jerek" of Czecho-Slovakia (keeping in mind that the dismembered country lost its freedom but gained a hyphen at this time).

It appeared certain that Ježek was finally going to have an opportunity to show the New York music world what he could do. But it was not to be. In a letter to to Jiří Voskovec from May $15^{\text {th }}$, 1941, he described some strange happenings:

Remember I told you earlier, that I read in the Times that the International Music Festival taking place in New York this month would play one of my pieces. Well you won't be able to look forward to this any more because my piece won't be played. I don't know the exact reasons, but I'm looking into it as much as I can. Everyone is blaming somebody else and no one wants to own up to it . . It's pretty obvious up that up till now I haven't been very lucky. But who cares? I'll start over again and we'll see later. In the mean time I'll keep composing and hope that I can write something while I'm still on this earth ... 


\section{And in This Corner a Terezin-Bound Composer ...}

What reason could there have been for pulling Ježek's work from the program? We still lack a complete explanation, and the point has been the source of some controversy within the Czech musical and scholarly community. In Happy Blues or From the Diaries of Jaroslav Ježek, František Cinger argues that somehow the diplomat Miloš Šafránek muscled Ježek out of the way to provide an opportunity for Bohuslav Martinů, whose Three Ricercares were played as part of the festival. But this seems unlikely. Martinů's work was played on an orchestral concert at some point in the Festival, perhaps with Šafránek's influence, but Ježek's Sonata had always been meant for a chamber recital. Cinger seems to assume that the ISCM chose only one person from each country, but as we can see from the article in the New York Times, there are at least two from several countries.

A better hint about what might have happened is given by Ježek's biographer, Vaclav Holzknecht who writes that:

Ježek started to sweat all the time and feel tired. His kidneys had already stopped working. And then something strange happened. The head of the jury was visited by a German musicologist, an emigrant from Bohemia, and it was decided that in place of Ježek's Sonata a piece composed by one of his German protégés would be played. It was put about that Ježek's Sonata had been lost. In the end Ježek was glad when the manuscript of the "lost" Sonata was returned to him, without apology. ${ }^{4}$

This is a pretty serious charge, especially considering that it is delivered without evidence or attribution. Could it have a ring or truth to it? Looking at the review of the concert, held on May 21, 1941, we note that in addition to composers such as Seiber, Dessau and Webern, we find mention of a Sonata by Viktor Ullmann. Could that have replaced the work by Ježek? And if so why? While definitive proof of anything is perilously hard to come by, and there is no such thing in this case, further light may be shown in the following discussion.

My personal primary source for German-speaking Czech musicologists has always been the eminent Ethnomusicologist, Prof. Bruno Nettl, whose father, Paul, was one of the most eminent musicologists of the pre-War era-indeed his name comes up as someone who was putting this concert program together. As I was working on this article, I contacted Bruno Nettl about this conundrum, and he quickly wrote back, saying that he thought his father might have been involved in some way, further noting that he was very much aware of the concert because his mother was the pianist for Ullmann's Piano Sonata.

Prof. Nettl offers this view on the issue: "I think it's possible that Paul Nettl tried to get the Ullmann sonata included in the ISCM program, although it is hard to imagine that he could have had much influence at the time. But I doubt very much that he would have been involved specifically in causing it to replace the Ježek sonata on the program. Aside from trying to help in enhancing Ullmann's reputation in North America, he may have also been hoping to further the

\footnotetext{
${ }^{4}$ Quoted from p. 121 in a Czech collection of short biographies by Vaclav Holzknecht, a "Little Medallion” book, Horizont Publishers, 1982. The most comprehensive online source is in Czech, available at: http://www.musicologica.cz/slovnik/hesla.php?op=heslo\&hid=3514
} 
career of my mother, Gertrud Hutter-Nettl, as a concert pianist, a career that had been cut short in Europe after 1938 and that she had up to that point been unable to resume in the USA.”

In order to try to make sense of all of this, it is important to consider what was at stake in these programs. Performers and composers live in a world apart, where often it is not necessarily what you write or how you play, but who hears you and where. Part of the power of the New York scene has always been the premise that, as the song goes, "if you can make it here you can make it anywhere." And for the performer artist, playwright, composer or dancer, the arbiter of this has usually been The New York Times. A good review from the Times could translate into further opportunities, and for émigré composers this would be a highly significant indicator of value.

Seen from the vantage point of the present day the entire tussle has a piercing, pathetic side to it. Think of it as a boxing match where only a single contestant gets to face the New York Times critic. In one corner, we have a blind and poor Czech jazz pianist, trying desperately to be noticed in the world of New York high culture, and soon to be dead of kidney failure. In the other corner we have a German-speaking Czech anthroposophist of Jewish ancestry several months away from a journey to Terezin and a final trip to Auschwitz, with many remarkable works in between. Is it possible to chart the agony of exile by imagining how we might choose between the two? We have no clear idea of what happened or the motivations of those involved, but at least it might be possible to understand why someone stuck in Prague might be given priority over someone already in the United States. Whatever the case though, there is no doubt about the fact that Ježek was treated shabbily, and unfairly, and there was no excuse for leaving him in the dark.

On the other hand, perhaps it was a good thing that Ježek was well out of this concert, because it was given about as devastating a review as any that can be found in the Times. If we imagine that the composers involved and their advocates may have viewed this New York concert as as a possible passport to fame or freedom, reading Olin Downes pan of the concert makes one's skin crawl. (See Figure 3.)

After making these snide and nasty comments about the first pieces on the program, by Seiber, Ullmann, and Webern, Downes confesses that he did not hear the Dessau composition that began the second half:

It went unheard by this reporter, as did the Schnabel sonata. The reason for this was that by the time the Webern quartet ended the room was as mephitic as the composition; that the windows, following the intermission, were hermetically closed, so to remain until the end of the concert; and that at this point nature rebelled.

Your correspondent left. He needed fresh air as much as the music.

Certainly we have no wish to have Olin Downes take the fall for Ullmann's fate, but his review offers a powerful example of the kinds of vast differences in perception exiles have to deal with on a daily basis. Considering the situation of refugees not fortunate enough to get into the United States and the conditions they were enduring at this time, and in coming years - I am thinking here of the idea of being packed into stifling trains and other horrible rooms-Downes' writing cannot but appear shockingly shallow. Ježek's general comment about such American attitudes was: "You can't let it get to you. They just don't know what's going on over there.” 


\section{CHAMBER PROGRAM HEARD AT LIBRÄRY

\author{
International Society Gives an \\ Offering of Contemporary \\ Compositions at Festival .
} \\ STRING QUARTET PLAYS \\ Viktor Ullman Sonata Follows -Roth Quartet,Performs, With Olga Forrai Singing}

\section{BY OLIN DOWNES}

This writer listened with complicated feelings last night to the concert of chamber compositions given in the New York Public Library by the International Society for Contemporary Music.

Perhaps the conditions were not ideal for hearing new music. It was a hot night. The hall allotted by the library authorities for the concert was small, with no great reserve of fresh'air if windows as well as the doors were closed, which was done when the concert had gotten into its stride for the better hearing of the performances.

There was the hope of some worthwhile new music, winnowed from the offerings of composers representing seventeen nations, or peoples, that the festival has brought this year to this country. There was and there is the desire to extend every possible hospitality of thought and ceed to this celebrated assembly, now exiled from Europe, where, since 1923, it has held its conventions.

\section{Seiber Work Heard}

And then one heard the music. For at least three-fifths of the program it was shockingly empty and affected; the extreme, indeed, of pose and egocentricity.

The program opened with a string quartet by Matyas Seiber of Hungary, music on the Schoenberg side, with a sort of longing, toward the end, for the fleshpots of Debussy. In fact there was not a little relationship between phases of this quartet and that of Anton Webern, a leading Schoenberg pupil, that came later: Music strenuously attempting. the original, and getting precisely nowhere.

That its ideas are dissonant is not necessarily for or against, since the dissonance of today is the accepted harmonic procedure of tomorrow. The point is the triteness of these ideas, their fussy and inconsequential treatment, the reliance on certain high-pitched effects of scoring, and the fruitless search for something to say that would be convincing. It is Dead Sea fruit, and Dead End music.

\section{Sonata Is Played}

Came a sonata by Viktor Uliman"independent"-a Czecho-Slovak by birth. This piece is as conventional at the base as the music of Seiber was artificial and forced into an unconvincing pattern. This composer cannot get away from the Schumann-Brahms romanticism, although he glosses over that now old-fashioned and outdated expression with ornaments of alleged modernity, overworking rather conventional rhythms and piano figures in the process, and this without achieving a genuine organic development. But how could music so conventionally imitative reach a genuine development?

The windows were now closed, because, as it was remarked, the delicate music of Webern could not be heard if they remained lopen. Not for this music the fresh air or the crude turbulences of the world. For it is the ultimate of orderly and deliberate disintegration. Ghosts of ghosts of ideas, wisps of tone are heard. For this skilifullye contrived piece exemplifies an admirably skillful way of saying nothing. Is it any wonder that the culture from which it emanates is even now going up in flames? To which is here added the plaint of the mosquito.

The performers last night were the Roth Quartet, which saw its duty and did it manfully; Gertrud Nettl, pianist, who played the Unlmann Sonata; Olga Forrai, soprano, with Brunno Eisner and Josef Wagner, pianists, in the Dessau ensemble, and Lydia Hoffmann-Behrend, pianist, for the Sonata of Artur Schnabel. Dessau's piece is scored for voice, piano, harmonium and two percussion, and is called, "Les Voix de Paul Verlaine à Anatole France." It went unheard by this reporter, as did the Schnabel sonata. The reason for this was that by the time the Webern quartet ended the room was as mephitic as the composition; that the 'windows, following the intermission, were hermetically closed, so to remain until the end of the concert; and

Your correspondent left. He needed fresh air as much as the music. 
While anyone interested in Ježek may regret that the sonata was not performed, and again, there is no actual evidence of any inappropriate maneuvering, one could not blame Nettl, or any other advocate, from trying to use the power of the New York Times as a way of trying to get figures like Ullmann out of danger.

\section{Ježek’s Dark Blue World}

The ISCM concert went off, without Ježek's piece, in the middle of May 1941. We have noted that Ježek was already in poor health, and indeed, he had only seven more months to live. In that time he completed a string quartet movement and a few final songs.

In late December his condition worsened dramatically, and he died on New Year's Day. The following clip from a biographical film, shows the calendar that marks the last days, and lists such things as "suffered the most-morphine; into the hospital; pneumonia, wedding (!), death."

\section{Video Example 3}

Accessible at: http://dx.doi.org/10.3998/mp.9460447.0002.201

In this part of the film, the images are accompanied by the song that became Ježek's anthem, "Tmavomodrý svět, or Dark Blue World," recently the title of a hit Czech film. Of all Ježek's songs, numbering around 200 in total, "Dark Blue World" has come to occupy a special position. Here is Jan Werich's description of its birth:

Our theatre toured around Czechoslovakia quite a lot, and our favourite destination was the city of Brno. It had a nice theatre and a great audience: students, young people, we loved performing there. Plus, we usually arrived in Brno in May and that's a beautiful month: there are lots of trees in blossom, the tulips flower, it's gorgeous.

And one year, during a sultry, hot May, Voskovec and I walked past the empty theatre and heard someone playing the piano. So we followed the music inside and as we walked onto the stage we found it in complete darkness, except for a single, bright shaft of sunlight which was coming from a window near the ceiling, illuminating the centre of the stage. And there, in the sunlight, sat Ježek who was improvising on the piano.

He was playing a blues. He played a few bars, stopped and went back to the beginning, again and again. When he saw the two of us, he stood up and said: 'It's too hot for this, guys, let's go and have a beer.' But we felt really touched by his playing and said: 'Wait, this is a great blues, let's finish it.' So he sat back down and started playing again, and, as if from nowhere, these words popped into Voskovec's and my heads:

[It isn't just, that it's dark,

but I cannot see.

I know that it's dark all around

Dark I cannot see.

I only see that I don't see a thing

If I could admit that I see

I would see more

Can't see my face, my two hands, I can't see my knees]

And we wrote the whole song, there and then. 
From this almost happenstance beginning (and we must always suspect the purity of origin myths), the song took on special significance. As we have noted, Ježek was practically blind, and could see only certain shapes and shadows; if he wished to see musical notation, he had to hold up the paper centimeters from his one "good" eye. Werich continues, describing what the song became for all of them:

At that time, Voskovec and I had no idea that in fact the words of the song expressed a kind of a 'life-blues' of Jaroslav Ježek himself. He only told us many years later, when we were all in exile in the United States, that he loved that song - and those words - most of all because they were about him really. He couldn't see very well, and he saw blue color best. That's why the study in his flat was painted blue, that's why he always wore a blue tie and that's why it's Dark BLUE World.

As Voskovec implies, the real character of the song only seemed to crystallize during Ježek's exile and after his death to gradually become a virtual manifestation of the composer himself. The notion of "the Dark Blue World" reached into every fold of Ježek's life, and could encompass anything from a lighter, worldly "bluesiness," to a description of physical reality as Ježek saw it, to something representing the essence of loss and exile.

This was also the point of a central and critical scene in the Czech film Dark Blue World. The young Czech flier, fighting with the RAF, has fallen for a British widow, and has just found out that his best friend is also in love with her. Late night drinking, etc.:

\section{Video Example 4: Scene from Dark Blue World}

Accessible at: http://dx.doi.org/10.3998/mp.9460447.0002.201

This is not the time or place for an extended discussion of just how musical details work together to create something like an identity for a song, but it seems to me that two primary musical features are essential here. First, the way the flat six goes from an ornamental to a structural role, becoming something like a musical manifestation of displacement. This culminates in the title words of the song: "Dark Blue":
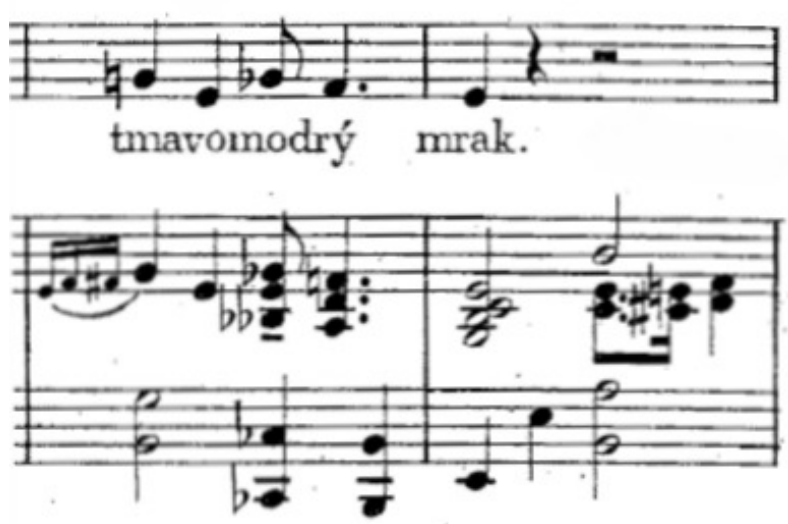
The other is the way the chorus, with its too-many-syllables-in-a-line gives the impression of stuttering, straggling, or deficit of some kind:

\section{Audio Example 4: "Dark Blue World"}

Accessible at: http://dx.doi.org/10.3998/mp.9460447.0002.201

The color theme in Ježek's life was amplified further by the reality that Ježek himself composed in something known as "The Blue Room," which exists to this very day in Prague just a few steps from the Old Town Square. It is interesting to note that according to today's doctors the color blue was probably the worst thing for Ježek's vision. So perhaps the color provided something else to the composer, a self styling reflected in the song:

\section{Video Example 5: "Dark Blue World"}

Accessible at: http://dx.doi.org/10.3998/mp.9460447.0002.201

There are other ways in which "Dark Blue World" has become emblematic of Ježek's life. Several years ago an astonishing piece of footage appeared. The Czech jazz musician, Jiří Stivín was apparently looking for a rumored film of an encounter between Ježek and Martinů and received a piece of tape from Ježek's widow Frances. It turned out to be a film of Ježek's funeral at the beginning of January 1942 in New York, in startling living color. Stivin unofficially adapted it as a kind of short "art film" and added, as his own arrangment of "Tmavomodrý svět" as a soundtrack.

\section{Video Example 6: Ježek's Funeral}

Accessible at: http://dx.doi.org/10.3998/mp.9460447.0002.201

From this melancholy filmlet we get an inevitable impression that "Dark Blue World" perfectly sums up Ježek's years of near-blindness, of exile, and finally of death. But this was a song written on a sunny afternoon in 1929 by a couple of young men; the composer was only 23, a composer who famously remarked while in the United States: "I don't like sweet and sentimental music.” Is there perhaps another story somewhere?

\section{The Exile in the Middle}

I would like to briefly look at the two inner movements of Ježek's Piano Sonata in search of another version of the composer's New York experience. While beginnings and endings get outsized play in traditional templates of form, it is obvious that in many cases composers speak their piece in the middle of works. The notion of $a-b-a$ implies the primacy of $a$ : after all it occurs first and occurs twice; that should make it more important-we speak of the "A-list" and "B-movies." Yet it is just as clear that $b$, appearing only once, and protected from the outside world, is an ideal place to hide that which is most special. Thus we might think of traditional formal designs as something 
like $b$-a-b instead, with the primary material in the middle. The two inner movements of this Sonata are no exception, and they are at the same time exceptional. The second movement may be said to look homeward. A kind of updated Smetana polka, it is simultaneously reminiscence and reformulation; with an edginess that is at the core of Ježek's work. Note the second-based dissonance on each beat.

\section{Audio Example 5: Ježek Piano Sonata, Movement II}

Accessible at: http://dx.doi.org/10.3998/mp.9460447.0002.201

We might note for the sake of comparison that the final form of Ježek's sonata is taking shape at the same time that Martinů, residing a few blocks away, is composing his Songs on One Page. In this comparison of two exiles, at least, Martinůs songs, containing some aching memories of the Moravian countryside, are the more nostalgic.

The third movement of Ježek's Sonata is one of his great creations. It begins with a kind of slow jazz without swing:

\section{Audio Example 6: Ježek Piano Sonata, Opening of Movement III}

Accessible at: http://dx.doi.org/10.3998/mp.9460447.0002.201

This gradually yields to what is perhaps Ježek's most potent synthesis of jazz and avant-garde music, fittingly in the middle of the middle:

\section{Audio Example 7: Ježek Piano Sonata, Excerpt from Movement III}

Accessible at: http://dx.doi.org/10.3998/mp.9460447.0002.201

What if we were to view some of Stivín's funeral film with a different soundtrack; this very middle section of the $3^{\text {rd }}$ movement of the "lost" piano sonata:

\section{Video Example 7: Ježek’s Funeral with Excerpt from Piano Sonata, III}

Accessible at: http://dx.doi.org/10.3998/mp.9460447.0002.201

What a different funeral, and what a different effect!

Of course such games of adding soundtracks to change the effect of moving images highlights the dangers of using music as a soundtrack for a life, for a life in exile, or in general trying to reduce something as complicated as any aspect of human life to a theme song. And further it cautions us not to write our history too dependent on larger theories about how one thinks it "was." It was always different. 


\section{Conclusion: This is How Much Home We Need}

In his writings about exile Amery says bluntly:

What misery. Whoever didn't know it was taught later by daily life in exile that the etymology of the German word for misery [Elend], whose early meaning implies exile, still contains its most accurate definition.

However, he goes on to qualify this, at least in part, in a later passage:

If I am permitted already at this point to give a first and tentative answer to the question of how much home a person needs, I would say: all the more, the less of it he can carry with him. For there is, after all, something like a transportable home, or at least an ersatz for home.

Amery goes on to talk about religion, money and fame as the kinds of things that might temporarily stand for home, but there are other ways to get there. In fact, there are plenty of passages in letters and diaries, where Ježek, like Dvořák before him, suggests that in some ways, he is happier in the New World than he was in the old. Exile is a complex business. Ježek was nearly blind, broke and struggling. But he became productive, he said things like: “Don’t forget I'm always an optimist. It's better that way, isn't it?”

Ježek was also in his element in a different way. In his interview with WOR Ježek said that among all musicians: "My real favorite is Duke Ellington.” Jan Werich also reported that when Ježek first got off the boat in New York broke, ill and with no prospects his first concern was not where he would find food or a roof over his head, but: "Where is Benny Goodman playing?"

\section{General comments about sources}

There are no important English language sources on Ježek and his work. In fact, the last scholarly monograph on the composer is Vaclav Holzknecht's 1957 volume Ježek and the Liberated Theater (Jaroslav Ježek a Osvobozené divadlo) published in Prague. Holzknecht subsequently wrote a "Little Medallion" book (a Czech collection of short biographies) published by Horizont publishers in 1982 with solid information. The most comprehensive online source is in Czech, available at: http://www.musicologica.cz/slovnik/hesla.php?op=heslo\&hid=3514

This contains a short biographical entry, and a complete and useful bibliography and work list. Information about Ježek's time in New York is found in Ježek's New York Diary (tiskarna New Yorkského Dennǐka) published in 1942. Another source for Ježek's time in New York is an interview with WOR radio. I have not been able to find the tape of this broadcast, and have thus been in the Mark Twain-like position of having to translate it from Czech since evidently Holzknecht did have access to it and it is printed in his second book. I am hoping the original does not appear to show up my translation . . . A newly published work on Ježek by the journalist František Cinger contains many passages unavailable elsewhere, though attributions are not always clear. The book is titled Happy Blues or From the Diary of Jaroslav Ježek (Š́tastné Blues aneb z deníku Jaroslava Ježka; Prague, 2006).

There are many sources for the Liberated Theater itself. One English language article is Jarka Burian's “The Liberated Theater of Voskovec and Werich,” published in 1977 by the Educational Theater Journal (Vol.29, No.2) available on JSTOR at www.jstor.org/pss/3206218 However, one 


\section{Music AND POLITICS Summer 2008}

can also get a sense of the theater from looking at clips available on YouTube by searching under Ježek. Many of the clips are from films, and do not quite capture the zaniness of the live experience, but they are a chance to hear Ježek's Big Band and get a sense of how it interacted with the two stars. The description of the composition of "Dark Blue World" is from a series of interviews with Werich available on compact disc. It was provided to me by Radek Boschetty of BBC Radio.

The material about Jean Amery and exile comes from At the Mind's Limits, published by Indiana University press in 1980. The first two chapters, “At the Mind's Limits," and "Torture," are relevant to the discussion of exile, but it is Chapter 3, "How Much Home Does a Person Need," that is literally at the center-of the book and the issue itself.

Michael Beckerman

New York City, 2008 